\title{
RECODIFICATION OF THE LAW IN THE NETHERLANDS \\ The New Civil Code experience
}

\author{
by E.H. Hondius*
}

1. INTRODUCTION

2. THE BACKGROUND TO THE RECODIFICATION EFFORT AND PRESENT STATE OF AFFAIRS

2.1 The Civil Code of 1838

2.2 Criticism of the Civil Code

2.3 Civil Code revision - the Meijers draft

2.4 Work on the New Civil Code after Meijers' death

2.5 Opposition to the new code

2.6 The present state of affairs

3. SOME GENERAL QUESTIONS

3.1 Codification versus restatement

3.2 Subject matter of the code

3.3 Structure of the new code

3.4 The code and the citizen

3.5 National unity versus international unity

3.6 A new code enters into force: evolution or revolution?

3.7 Re-educating the legal profession

* Professor of Civil Law, University of Utrecht. 
"The principle of justice is, that law should be known by all; and for its being known, codification is absolutely essential."

Jeremy Bentham

\section{INTRODUCTION}

It now looks as though the middle of the 1980's will mark an important turning point in the development of Dutch civil law. By that time, books 3-6 and some parts of book 7 of the New Civil Code will probably have entered into force in the Netherlands. Two books have already come into force and it is expected that after 1985 the remaining parts of book 7 and book 8 will soon follow suit.

In this paper, I shall try to present a picture of the Dutch recodification effort and of some of the theoretical and practical problems which it has raised. I shall deal only with the new civil code; this is only one part of the law, although admittedly an important part. There are certainly other parts of the law which are also the object of a (re)codification effort. The Dutch Constitution is well on the way to a complete revision ${ }^{1}$, and the groundwork for a codification of the law of administrative procedure ${ }^{2}$ and for a code of social security law ${ }^{3}$ has already been done. However, it is the recodification of the civil law, which has attracted most attention, both within the Netherlands ${ }^{4}$ and abroad ${ }^{5}$ and this presents us with most of the basic questions regarding (re)codification of the law in general.

1. M.C. Burkens, The Complete Revision of the Dutch Constitution, 29 NILR 323-336(1982).

2. Algemene bepalingen van administratief recht, 1st edition 1953, with several later editions.

3. G.M.J. Veldkamp, De vereenvoudiging en codificatie van het Nederlands sociale zekerheidsrecht, Sociaal Maandblad Arbeid 1975, 580-588.

4. See C.J. van Zeben and G.J.L. Seesink (eds.), Nieuw Burgerlijk Wetboek, Deventer 1959(loose-leaf), Literatuuroverzicht, which contains some 1,000 references.

5. See Jürgen Basedow, Grundfragen der Vertragsrechtreform: Niederländische Erfahrungen, Zeitschrift für vergleichende Rechtswissenschaft 1980, 132-148; J. Dainow, Civil code gevision in the Netherlands; the fifty questions, 5 American Journal of Comparative Law 595610 (1956); J. Dainow, Civil code revision in the Netherlands; general problems, 17 Louisiana Law Review 273-293 (1957); J. Dainow, Civil code revision in the Netherlands: some new developments in obligations and property, in: XXth Century comparative and conflicts law (Legal essays in honour of Hessel E. Yntema), Leyden 1961, 172-189; T.J. Dorhout Mees, Het ontwerp voor een Nieuw Burgerlijk Wetboek, Mededelingen van de Koninklijke Vlaamse Academie voor wetenschappen, letteren en schone kunsten, Brussels 1964; H. Drion, Introduction to Book 6 of the Draft Civil Code of the Netherlands, 17 NII.R 225-237 (1970); A.S. Hartkamp, Civil code revision in the Netherlands; a survey of its system and contents, and its influence on Dutch legal practice, 35 Louisiana Law Review 1059-1090 (1975); A.S. Hartkamp, Vers un nouveau Code civil néerlandais, Revue internationale de droit comparé 1982, 319; G.E. Langemeijer, La réforme du Code civil néerlandais, Revue internationale de droit comparé 1965, 55-72; F.H. Lawson, 12 International \& Comparative Law Quaterly 1071 1072 (1963); E.M. Meijers, La réforme du code civil néerlandais, Verzamelde Privaatrechtelijke Opstellen 1954, I, 150-173; E.M. Meijers, La révision du code civil néerlandais, Verzamelde Privaatrechtelijke Opstellen 1954, I, 194-204; A. von Overbeck, Zeitschrift für Rechtsvergleichung 1962, 190-191; A. Pitlo, Projet pour un nouveau code civil néerlandais, Revue inter- 
First, I shall briefly outline the background to the civil law recodification and the present state of affairs. Then, in Section 3, I shall analyse some of the features of this recodification effort from a more general point of view.

\section{THE BACKGROUND TO THE RECODIFICATION EFFORT AND PRESENT STATE OF AFFAIRS}

\section{$2.1 \quad$ The Civil Code of $\mathbf{1 8 3 8}$}

The idea of codification ${ }^{6}$ was first taken up by the Dutch legislature in the aftermath of the French Revolution ${ }^{7}$. Article 28 of the first constitution (1798) of the Bataafsche Republiek laid down that '. . . a Code of Civil Law as well as of Criminal Law shall be drawn up, at the same time as the Law of Procedure, on the basis of the Constitution and uniform for the whole Republic. They shall eriter into force within two years after the Constitution has entered into force'. This provision was undoubtedly inspired by the developments in France, although it should be remarked that the main argument advanced in favour of codification in France - the uncertainty and confusion caused by the unpredictability of court decisions ('Dieu nous protège de l'équité des Parlements') - did not apply to the same extent in the Netherlands. It was rather the (geographical) unification of the law - in France no more than an additional aim ${ }^{8}$ - which was the primary purpose of codification in the Dutch Republic, as was explained in a letter of 19 August 1796 addressed to the National Assembly ${ }^{9}$.

The second paragraph of Article 28 of the 1798 Constitution notwithstanding, it was to be another thirteen years before codification of the law was attained by the imposition of French law including the Code Napoléon in 1811, at a time when the Netherlands had been annexed into the French Empire. In the meantime, several draft civil codes had been drawn up ${ }^{10}$, but only one of these entered into force, and then only for two years.

nationale de droit comparé 1956, 39-53, T.B. Smith, The influence abroad of the modern Dutch movement for code revision, Weekblad voor privaatrecht, notariaat en registratie (WPNR) 1980, 55-61; W. Snijders, Vers un nouveau code civil nćerlandais: état des travaux, Revue de droit international et de droit comparé 1979, 223-231.

6. The term 'codification' was coined by Bentham.

7. Arguments have been made in favour of codification before the establishment of the Bataafsche Republiek in 1795 - see J.M.J. Chorus, Hoofdstukken uit de geschiedenis van de kodifikatie van het privaatrecht in West-Europa. Amsterdam 1979 (mimeograpl.ed document University of Amsterdam), 36-45 and H. Cohen Jehoram, Over codificatie/Van voor Portalis tot na Meijers, second ed. Deventer 1970, 1-21. However, because of the absence of any central authority (Republic of the Seven United Netherlands) one of the major requirements for codification did not exist before 1795 .

8. See J. van Kan, Les efforts de codification en France/Etude historique et psychologique, Paris 1929.

9. Chorus, o.c. (footnote 7), 86 .

10. The first draft was drawn up by a commission, in which the most influential member was the Amsterdam Professor Cras; this draft was rejected for being too erudite and theoretical. A highly practical and clear Civil Code was drafted by the Amsterdam practising attorney J, van der Linden. Finally, a draft 'Code Napoléon adapted to the Kingdom of Holland' was drawn up 
After the re-establishment of Dutch independence, a restoration movement naturally followed, which opposed the changes brought about by the French Revolution. One of its achievements was a new, more Dutch-oriented draft civil code (the so-called Draft Kemper, 1820), which was, however, rejected by Parliament. At that time, the Northern Netherlands were united with the more populous Southern Netherlands, which feared northern influence and favoured the Code Napoléon. As a result, the Burgerlijk Wetboek (Civil Code) which was finally adopted in 1830 , was heavily influenced by, and partially even translated directly from the French Civil Code. Ironically, it was in that very year (1830) that Belgium broke away from the Kingdom. Subsequently both countries went their own way ${ }^{11}$; Belgium retained the French code while the (northern) Netherlands finally introduced the 1830 code, with some minor amendments, in $1838 / 1842^{12}$.

\subsection{Criticism of the Civil Code}

The Burgerlijk Wetboek came under attack even in the nineteenth century, ${ }^{13}$ though to a far greater extent during the twentieth century, mainly from learned writers. Criticism of the code may be subdivided under several headings. First, the structure of the code was criticised, even though it was generally considered to be superior to the French code. Criticism arose as a result of a changing perception of the various areas of the law: the law of inheritance was no longer considered predominantly to concern the acquisition of property, a need was felt for general provisions regarding agency and legal acts, the division between civil and commercial law became less important. Substantive changes were also advocated, in such areas as divorce law, the law of torts and the law of evidence.

Since the legislature did not respond to calls for change, except with regard to contracts which were of interest to the electorate (such as the labour contract, hire-purchase and rent), the courts under the direction of the Hoge Raad felt obliged to step in and did step in. As a result, legal development in the Netherlands has increasingly taken the form of case law, to such an extent that the Dutch system is now sometimes - incorrectly in my opinion ${ }^{14}$ - described as being midway between a continental code law country and a common law country. At

during the short reign of Louis Napoleon, the brother of the Emperor (1806-1810). Only the latter code came into force, in 1809 , but two years later, in 1811 , it was replaced by the French Code Napoléon.

11. On the subject of the separate legal development in Belgium and The Netherlands, see Eg. Spanoghe and R. Feenstra (eds.), Honderdvijftig jaar rechtsleven in Belgiê en Nederland 1830-1980, The Hague 1981.

12. The Civil Code, Commercial Code, Code of Civil Procedure, Code of Criminal Procedure and Judicial Organisation Act entered into force on 1 October 1838, in the province of Limburg on 1 January 1842.

13. Nineteenth century criticism often focused on the wording of the texts and other deficiencies in legislative technique - see A. Fontein, A century of codification in Holland, 21 Journal of comparative legislation and international law 81, 84-85 (1939).

14. Legislation is still the framework for deciding cases and moreover is considered to be all-embracing; both aspects are in contrast to the common law system. 
any rate, there is some truth in the Italian description of our time as an era of decodification ${ }^{15}$.

Although criticism of the Civil Code was widespread by the time it had been in existence for a hundred years, it rarely aimed at recodification ${ }^{16}$. Even among those who advocated adoption of a new code, there was no Voltairian 'Voulez-vous avoir des bonnes lois? Brûlez les vôtres, et faites-en des nouvelles'. The revisionist attitude may rather be illustrated by the following quotation: 'Revision is urgently needed; it is possible. It is not necessary to do afresh all the work done a century ago, but we should strive to put the codes once more into a form which will make them understood by the ordinary law-abiding citizen'16. However, there is little doubt that the prevailing opinion by 1938 may best be summarised in the famous words of Paul Scholten: 'Our Civil Code is a quiet possession,17.

\subsection{Civil Code Revision - The Meijers Draft}

There is no evidence that the prevailing opinion concerning the lack of necessity for a revision of the Civil Code had changed by the end of World War II. A movement to reform Dutch society after the end of the war, which was soon replaced by a strong restoration movement, certainly did exist. However, this movement does not seem to have made a point of revising the Civil Code.

It therefore came as a surprise, when by Royal Decree of 25 April 1947 E.M. Meijers was entrusted with the task of revising the Civil Code. The background to this decree is still shrouded in mystery. The decree was issued after a Member of the First Chamber of Parliament (the 'Senate') had criticised the 1838 code as being out of date and had suggested asking Meijers to revise it. However, the short period between this suggestion, made on 5 March 1947, and the Royal Decree, suggests that the Government might have considered the matter previously.

A partial answer to the question why the decree was issued may be supplied by the following. Meijers was generally agreed to be one of the two or three most outstanding lawyers of the first half of this century, the others being Paul Scholten and J. Eggens; the latter was later to play a role in the recodification effort. It was also generally known that Meijers was the most prominent advocate of a Civil Code revision ${ }^{18}$ and had actually made notes on the changes he considered to be necessary ${ }^{19}$. Finally, it might have been considered appropriate to bestow

15. See A. de Cupis, A proposito di codice e di decodificazione, Rivista di diritto civile $1979,47-53$.

16. Fontein, 21 Journal of Comparative Legislation and International Law 81, at 88 (1939).

17. Paul Scholten, De codificatie-gedachte vóór honderd jaar en thans, Gedenkboek BW 1838-1939, Zwolle 1938, 1.

18. In his essay 'Het feillooze deel van ons Burgerlijk Wetboek' ('the infallible part of our Civil Code'), WPNR 1928 nr. 3031, Meijers published a list of 100 code articles which were in need of a revision. In his contribution 'Wijzingen en aanvullingen van het Burgerlijk Wetboek na 1838' in Gedenkboek BW 1838-1938, 61 Meijers pleaded for a revision of the Civil Code, which at that time had been in existence for a hundred years.

19. Meijers had envisaged a New Civil Code in his early years - J.C. van Oven, Rechtsge- 
the honour of revising the code upon someone, who had become a national figure following his dismissal from his Leyden professorship in 1941 by the German occupiers and because of his unbroken spirit during his internment in concentration camps. ${ }^{20}$

Whatever the background to the decree, Meijers at once went at work. He first drafted fifty-two questions which he submitted to Parliament ${ }^{21}$. On the basis of the answers, Meijers then began drafting a completely new code ${ }^{22}$. Originally he planned to publish the whole draft as one piece. Work proved more cumbersome than he had anticipated, however, and therefore the first four books and a preliminary title were published separately in 1954. Another five books were still to be drafted. However, at this point Meijers died. With the project half completed what was to be done: should it be continued or should it be abandoned?

\subsection{Work on the Civil Code after Meijers' Death}

After Meijers' death there seems to have been little doubt that the Civil Code revision should be completed. Meijers had left sketches for books 5 and 6 and some rough outlines for books 7,8 and 9 . Since no single lawyer was thought to be capable of completing the revision process, three successors to Meijers were appointed: J. Drion, F.J. de Jong and J. Eggens. (The latter was succeeded by G. de Grooth in 1958.) These three men drafted Books 5 (published in 1957) and 6 (published in 1960). The dates show that the revision process slowed down. Although Books 1 (Family Law) and 2 (Juristic Persons) were enacted in 1958 and 1960 respectively, they did not enter into force. More importantly, work on the other books slowed down considerably. As more and more lawyers were involved in drafting new parts and redrafting old parts, completing the revision sometimes seemed an impossible task. Even the fact that Book 1 entered into force in 1970 and Book 2 in 1976 did not alter this. Indeed, the enactment of Books 1 and 2 did not necessarily entail the adoption of the other books.

It is probably thanks to one gifted lawyer, that the revision process is likely to be brought to a happy conclusion. Since 1970, W. Snijders, a Justice in the Hoge Raad, has been in charge of the New Civil Code as special Counsel to the Government. Thanks to his efforts, the existing drafts were modernised, simplified, and re-organised. Even the opponents of a New Civil Code have admitted that the Snijders drafts are a superb piece of work.

leerd Magazijn Themis 1950,110. On the subject of the notes which Meijers made in antipation of a new code, see W.M. Kleijn and M.M. Olthof, WPNR 1981 nrs. 5561/5562.

20. See K. Wiersma, Meijers en de hercodificatie, WPNR $1980 \mathrm{nr}$. 5504, p. 28, who advances two other possible reasons: first, at that time the Ministry of Justice was severely criticised for its handling of war criminals and this positive act might have diverted attention; secondly, the recodification effort was probably underestimated.

21. J. Dainow, o.c. (see footnote 5 supra).

22. As in the Netherlands, plans for recodification were also launched in France in 1947. These plans eventually led to the replacement, modification or addition of some 1,000 articles - out of 2,283 - of the French Civil Code. However, the code's structure was not altered. See D. Tallon, Codification and consolidation of the law at the present time, 14 Israel Law Review $1 \mathrm{ff}(1979)$. 
From the outset, the idea of civil code revision met with hostility from a number of leading jurists. The most prominent of these was Pitlo, who on numerous occasions issued a ceterum censeo ${ }^{23}$. Pitlo was later joined by others who did not like the Meijers drafts.

On the other hand, most leading jurists, especially those from the 'establishment', favoured the revision process. They were later joined by some of the original opponents, who had been won over by the amendments proposed by Snijders ${ }^{24}$.

In parliament, the number of members who were really interested in the revision process dwindled as the number of lawyer members went down over the years. Within the Permanent Justice Commission of the Second Chamber, the proponents of a new code always seem to have been a large majority. It was only occasionally suggested that work on the code be halted ${ }^{25}$.

The opponents were never able to form a combined anti-revision front, since their criticism was so diverse. Criticism ranged from purely practical motives - the heavy burden imposed upon lawyers who would need an intensive re-education programme, the probable lack of legal certainty following the entry into force of the new code, the impediment to European integration by breaking away from timehonoured concepts, etc. - to theoretical arguments: the new civil code was considered to be too abstract, too learned, the subject-matter was considered to be too old-fashioned ${ }^{26}$.

Opposition to the New Civil Code seems to have reached a high point in 1977. In that year, the Second Chamber of Parliament had either to adopt or to dismiss altogether Books 3, 5 and 6, at what seemed to be a point of no return. By unanimously adopting the central part of the code, the Second Chamber gave the ministry the go-ahead to proceed with the civil code revision. Together with two or three other spectators, I was present at the historic parliamentary session, which began an hour late because of an insufficient quorum, and I am convinced that two last minute publications by critics of the new code actually helped the code to get through with such a large majority. Indeed, these two authorities seem to have needlessly antagonised the members of parliament by stressing the incompetence of the Second Chamber ${ }^{27}$.

23. See among other publications A. Pílo, Enige bezwaren tegen de huidige vernieuwing van ons burgerlijke wetboek, in: Het ontwerp B.W., Deventer 1961, 19-34. In the Revue internationale de droit comparé 1956, 39, 53 Pitlo was still enthusiastic about the project.

24. Including H.C.F. Schoordijk, who in his book 'Het algemeen gedeelte van het verbintenissenrecht naar het nieuw burgerlijk wetboek', Deventer 1979 (the first full-length treatise on Book 6 of the New Civil Code) praises the quality of Book 6, whereas in earlier publications he had criticised previous drafts.

25. By the representatives Jurgens (Radical Party) in 1975 and by senator Kaulingfreks (Catholic Party) in 1976, both without the backing of their parties.

26. J.M. van Dunné, Het werk aan het Nieuw BW; jeugdsentiment uit de jaren vijftig?, Nederlands Juristenblad 1977, 342-346; F.W. Grosheide, Invoering vermogensrecht NBW aanstaande? Of beter ten halve gekeerd dan ten hele gedwaald?, WPNR 1977 nrs. 5407/5408; P. Zonderland, Nieuw vermogensrecht als hamerstuk?, Nederlands Juristenblad 1977, 410-414.

27. This personal observation is supported by B. de Gaaij Fortman (the key speaker in the 
In the historical development of a provision of the New Civil Code roughly four periods may be distinguished. First, there is the Meijers draft. (Even after Meijers' death the official drafts were still called "Meijers draft.") Then a government bill is submitted to parliament. The government bill basically follows the Meijers draft, although not in every respect. After lengthy parliamentary proceedings, the bill is enacted and becomes a law. This is by no means the last stage. Then there is the difficult process of adapting other legislation to the new code, of providing for inter-temporal law and of making last minute amendments both regarding the enacted Code and other laws. A new bill, or new bills, are lodged with parliament, which once again takes its time to deliberate.

Unfortunately, interest in the New Civil Code from members of parliament is not what it used to be. Back in 1952, when Meijers presented his 'fifty questions' to parliament, many issues were heavily debated. At present, parliament has few lawyer members and technical questions are left to the specialists. Actually, most of parliament's work on the New Civil Code is done by the Second Chamber's Justice Commission, its counterpart in the First Chamber and by their Secretaries (who are legal experts).

One body has not yet been mentioned, i.e., the Raad van State (Council of State), which advises the Government on all bills, and therefore also on the New Civil Code bills, both those submitted to parliament to enact the Code, and those to cause the Code to enter into force. Until recently, the Council's influence on legislation was an unknown quantity, but it was probably not as significant as now. At present, the Council's opinions are published and it appears that the New Civil Code has received its special attention. Possibly the presence of a number of former law professors within the Council accounts for this surprising interest.

Following this summary sketch of the revision procedure, I shall now try to describe to what extent work has proceeded so far. As was mentioned above, Books 1 and 2 entered into force in the 1970's. Book 3 (General Part of Patrimonial Law), Book 4 (Succession Law), Book 5 (Property Law) and Book 6 (General Part of the Law of Obligations) have been enacted, but have not yet entered into force. Bills pertaining to various parts of these books have been lodged with Parliament as of 1981 , and it is not expected that these will cause any major difficulties, with the possible exceptions of the provisions dealing with the inheritance of the surviving spouse and of the new regulation of standard contract terms.

Book 7 (Specific Contracts) was published in the form of a Meijers draft bill in 1972. By 1981, two titles - those on sales and on donation - had been presented to Parliament as a bill. It is the government's intention to have the titles on sales (with the exception of hire-purchase), donation and some other specific contracts enter into force at the same time as Books 3-6, because of the close relation between the general part of the law of obligations and these specific contracts.

parliamentary discussion), in: Problemen van wetgeving, Deventer 1982, 43, 65. Generally 
Book 8 (Transport) was partly enacted in 1979, part of it has still to be enacted. Although this book is not closely connected to Books 3-6, it is now expected that it will have entered into force by the same time, or possibly shortly after.

The prospects for a Book 9 are rather gloomy. Meijers had conceived of a separate book on the "rights of creative man" (copyright, patent, trademark). He had been reproved by parliament for his daring terminology - "only God can create". However, another development has made the need for a book on industrial and intellectual property superfluous. The Benelux countries have adopted a number of uniform laws on this subject and it seems highly unlikely that these laws, with their different structure and their separate numbering, will be incorporated into the new code.

Another Meijers project which will not be adopted, is his Preliminary Title, dealing, inter alia, with the relation between the various sources of law (legislation, case law, custom, equity). A bill with this title was lodged with parliament in 1954, but the title was heavily criticised and parliamentary work on the bill was "temporarily" halted, in order to take into account the various books of the new code. In 1981, the government finally announced its intention of abandoning the Preliminary Title, with the exception of three provisions, which are to be incorporated in Book 3.

\section{SOME GENERAL QUESTIONS}

\subsection{Codification Versus Restatement}

At one of the crucial points in the history of the New Civil Code, i.e. the time of the adoption of Books 3, 5 and 6 by the Second Chamber of Parliament ${ }^{28}$, one critic advised against abandoning the recodification project altogether and suggested reverting to a restatement of the civil law ${ }^{29}$. In this way, all the work that had already been done would not have been in vain.

What difference does it in fact make, whether the law is (re)codified or restated $?^{30}$ Both a civil code and a restatement may be considered to be codes in many respects. They consist of a uniform body of rules, which were previously to be found in a number of different sources; they encompass the whole of the law, or an important part of it; they have the purpose (inter alia) of making the law more accessible $^{31}$. Obviously a major obstacle to calling a restatement a code is that it does not have the force of law. A restatement is merely an authoritative treatise,

speaking, academic writers have not always shown Parliament due respect: in Nederlands Juristenblad 1976, 1189, 1201 W.C.L. van der Grinten suggested that Parliament should refrain from amending the code's text. This suggestion was not accepted enthusiastically by Parliament.

28. Section 2.5 supra.

29. Van Dunné, Nederlands Juristenblad 1977,342 at 345.

30. Not very much, according to James Gordley, European codes and Ameridan restatements: some difficulties, 81 Columbia Law Review 140-157 (1981).

31. See J. Vanderlinden, Le concept de code en Europe occidentale du XIIIe au XIXe siècle/Essai de définition, Brussels 1967; idem, Code et codification dans la pensée de Jeremy Bentham, Tijdschrift voor Privaatrechtsgeschiedenis 1964, 45-78. 
which derives its force from the authority of those who drafted it and the procedure they followed in the drafting process.

According to most definitions, a restatement would therefore not be considered to be a code. I have some reservations about this. Both in the Netherlands and abroad there are several private compilations of trading rules and standards and I would not hesitate to call these "codes of practice" a code. However, with regard to the New Civil Code, it must be admitted that only a code with force of law would conform to the constitutional requirement of codification of the civil law. In addition to this formal argument, there is a substantive argument in favour of a code with binding force. There is little doubt that in general a law has greater authority than a restatement. This may be illustrated by the fact that, when considering whether or not to apply a New Civil Code provision which has not yet entered into force, the question whether parliament has already approved the provision certainly plays a role ${ }^{32}$.

\subsection{Subject Matter of the Code}

A major objective of any (re)codification effort - and this is even included in Vanderlinden's definition of a code - is that it should facilitate access to the law. This may be achieved by the following measures: finding a suitable subject matter for codification and arranging this in an orderly fashion in clear and unambiguous language. In this paragraph, I shall deal with the first measure: finding a suitable subject matter. The other measures will be dealt with in the following paragraphs.

The subject matter of the New Civil Code is the whole area of private law. A major innovation of the new code is the integration of the old Civil Code and the old Commercial Code into a new code, encompassing all substantive private law (procedural private law is still regulated in a separate code: the Code of Civil Procedure). This brings to an end a movement, which had already gained momentum by the end of the nineteenth century, aimed at reducing the differences between the private citizen and the tradesman ${ }^{33}$. Should a civil code encompass the whole of private law? In some countries, the legislature has taken considerable pains to ensure that the major reforms are carried out within the code ${ }^{34}$. Other countries, however, have adopted important laws which remain outside the main code. A prime example is the German $A G B-$ Gesetz $^{35}$, one of the most important reforms of German civil law, which was not integrated into the Bürgerliches Gesetzbuch mainly due to lack of time.

32. Section 3.6 infra.

33. Paradoxically, one of the major innovations of the New Civil Code will be the introduction of the consumer transaction; thus, the old distinction between private citizen and tradesman will return in a different guise - and within one code.

34. A good example is Switzerland, where major reforms of hire-purchase law, the employment contract and consumer credit have been or are being carried out within the Obligationenrecht (Law of Obligations).

35. Gesetz zur Regelung des Rechts der Allgemeinen Geschäftsbedingungen (Standard Contract Terms Act) of 1976 . 
Leaving important reform legislation outside the main body of codification has two major disadvantages. First, it may mean that the code and the reform law are not very well integrated. An example of this in Dutch law is the problem of integrating the cooling-off period for door-to-door sales of the Colportagewet into the ways contracts may be terminated as laid down in the Civil $\operatorname{Code}^{36}$. A second disadvantage is that reform legislation which is left outside the main code will be treated by the courts as an exception, because its principles are limited to its own subject matter. This may result in the main code not being influenced by the spirit of reform legislation.

In the German Federal Republic the $A G B$-Gesetz seems to be the last major (private) law which was drawn up outside the Civil Code. The travt: contract has already been drawn up within the Civil Code and there is a further trend to reintroduce into the Civil Code ${ }^{37}$ the separate laws such as the Abzahlungsgesetz (Hirepurchase Act), the Fernunterrichtsschutzgesetz (Long distance education Act) and the $A G B-G e s e t z^{38}$.

In the Netherlands there is a similar movement to incorporate into the Civil Code separate laws which deal with civil law. Surprisingly, however, this movement seems to be somewhat independent from the recodification effort itself. Thus, the law on the termination of rent contracts for real estate is no longer seen as a temporary emergency measure and has therefore recently been incorporated into the Civil Code. Similarly, the law dealing with the public authorisation of dismissal from an employment contract may be incorporated into the Civil Code.

In only one instance has the recodification movement itself led to the inclusion of a formerly separate law in the new code. At present, the Pachtwet (Land Tenure Act) deals with private, administrative and procedural aspects of land tenure. In the draft Book 7 of the New Civil Code, the substantive private provisions of the Pachtwet have been moved to a new place. The splitting up of land tenure law has been criticized by Dutch legal experts ${ }^{39}$. According to the critics, land tenure law will be less accessible, when it is spread out over a number of different laws or codes.

If this argument were to be taken seriously, it would mean that the whole question of recodification should be reconsidered. It has indeed been argued by one of the critics of the New Civil Code, that a functional approach would be preferable $^{40}$ to the question of which subject matter should be codified.

36. M.J.P. Verburgh, De Colportagewet: voer voor maatschappijcritici en civilisten, Nederlands Juristenblad 1975, 1237-1245.

37. H.G. Landfermann, Die Überarbeitung des deutschen Schuldrechts aus internationalrechtlicher Sicht, RabelsZeitschrift 1981, 124.

38. A list drawn up by the German Federal Ministry of Justice includes some 250 laws and decrees with provisions in the area of the law of obligations - cf. A. Wolf, Weiterentwicklung und Überarbeitung des Schuldrechts, Zeitschrift für Rechtspolitik 1978, 249.

39. See the opposing views of J. van Andel, De pachtovereenkomst in het nieuwe BW?, WPNR 1974 nr. 5258 and J. Rombach, De pachtovereenkomst in het nieuwe BW?, Pacht 1974, $190 \mathrm{ff}$.

40. Grosheide, o.c. (see footnote 26 supra). 
I would not subscribe to this proposal. It would mean the end of the general part of the civil law, or would at least be a severe blow to it. It would also entail fresh difficulties with regard to the new functions to be regulated ${ }^{41}$. Finally, a functional approach to the codification effort would result in a serious break with other West European legal systems, thereby depriving the Dutch legal order of the opportunity available at present of retaining ideas from the German, Swiss, Austrian, French and Belgian legal systems.

This leaves us with the question of what to do with the administrative law provisions dealing with land tenure law, or dealing with any other part of the law. In the past I have advocated that there is nothing against including some administrative law in a Civil Code, provided that the administrative law provisions are not too long or too detailed. Indeed Book 1 (Law of Persons and Family) already includes a number of public law provisions, as does Book 2 (Legal Persons). Moreover, when dealing with the question of which provisions should be included in the New Civil Code and which in the Code of Civil Procedure, the Dutch authors of the draft have taken a pragmatic view, which has resulted in the inclusion of several procedural provisions ian the Civil Code.

It must be admitted that my ideas with regard to administrative law have not met with wide acclaim, especially from the legislature. One of the reasons which have been advanced for abandoning the project of a ninth book on intellectual and industrial property is precisely that this part of the law is so interwoven with public law.

It is not only administrative law dealing with predominantly private law figures that has been left out of the New Civil Code. A less important omission is that of those business transactions which are regulated by privately drafted standard contract terms. These have often been dealt with summarily or even have been left out altogether. Thus, contracts like the charter contract have been regulated in a general way, while the banking contract, the construction contract and the towage contract have not been regulated separately at all ${ }^{42}$. This is deplorable, since it leaves the courts without a legislative yardstick: under the proposed provisions on unfair standard contract terms they have to consider the reasonableness of standard terms incorporated into such contracts.

It should not be concluded from the above, that all civil law should necessarily be incorporated in a code. Since the Dutch constitution has allowed civil law to be outside the code (since 1887), this possibility has also been utilised to regulate detailed provisions in separate laws. Even the New Civil Code itself orders several subjects to be regulated by law; two examples are the public land registers and the composition and terms of reference of the commissions charged with the drafting of standard regulations.

41. F.g.: construction law, environmental law and urban planning law overlap in many areas.

42. See my thesis Standaardvoorwaarden, Deventer 1978, p. 634-635. 


\subsection{Structure of the New Code}

An important way of making codified law more accessible is the orderly arrangement of the subject matter. As far as its system is concerned, the New Civil Code seems to be well-thought out, though it might have an excessively theoretical nature.

The main innovation of the new code, compared with thu present Civil Code, is the introduction of a General Part (Book 3). This general part is not applicable to the whole of private law: the law of persons and family (Book 1) and of legal persons (Book 2) are not included in its scope of application. Book 3 has met with a mixed reception.

On the one hand, the new regulation of juridical acts (rechtshandelingen) in general - as opposed to the present regulation of only the most important legal acts, such as contracts - has been praised, even by those who are of the opinion that the separation of provisions on juridical acts and contracts may cause some practical problems with regard to finding one's way in the new code. Similarly, most writers have approved of the new title on agency.

On the other hand, the new place for provisions which are common for tangible and intangible goods and rights has been severely criticised. This aspect has certainly become an important new feature of the new Dutch code. Meijers had apparently been annoyed by the inconsistencies of the present code regarding intangible goods and rights. For this reason he reduced the scope of eigendom (property) and of limited rights in rem to tangible goods. These provisions, together with some rules of traditional zakenrecht (property law), are now dealt with in Book 5. Those provisions which are applicable to both tangible and intangible goods and rights have been included in Book 3. As a result, property law is divided between two books, whereas traditional civil codes do not make any distinction. Another consequence is that it has been necessary to find a new terminology for old concepts. Now that eigendom applies only to tangibles, the legislature has had to find a new term to denote property of both tangible and intangible goods and rights.

There are other new features, but the above is just one illustration of the difficulties which Meijers' often somewhat dogmatic approach may cause in practice. The practical problems are mainly caused by the fact that the new code reveals a multi-layer system. The formation of a sales contract, for instance, is dealt with in titles 7.1 (on sale of goods), 6.5 (on contract) and 3.2 (on juridical acts). Finding one's way in the code is complicated by the inclusion of cross-references, the socalled schakelbepalingen (chain provisions) ${ }^{43}$. These provisions state that certain rules are also applicable, by way of analogy, to juridical acts or circumstances which fall outside their direct scope of application.

43. The term was coined by P. Neleman, Vaststelling boeken 3, 5 en 6 NBW, Ars Aequi 1980, 511-515. 


\subsection{The Code and the Citizen}

A civil code should be drafted in language which is clear to everyone; it should not go into too much detail. These were two of the major principles advocated by Eugen Huber, the author of the Swiss Zivilgesetzbuch (ZGB). The ZGB was intended to be accessible to every Swiss household ${ }^{44}$. Indeed, the ZGB and its supplement, the Obligationenrecht (OR), are considered to be examples of codes which can be understood by ordinary citizens.

This is not true of the present Dutch code, which contains cryptic provisions such as "With regard to personal property, possession is considered to be full title" ("possession vaut titre"). Surprisingly, the New Civil Code is almost as difficult to understand. One often gets the impression that the new provisions are directed more towards the courts than towards the citizens. Sometimes the explanatory memorandum is quite explicit in this respect. Thus, the omission in the new code of construction maxims for contracts is defended by the argument that the maxims in the present code are so self-evident for a court, that they do not need recodification.

There has been widespread criticism of several regulations in earlier drafts, which were considered to be far too complex and too detailed. The present policy of the legislature is to make a distinction between those provisions which prescribe a certain conduct, and those which provide what the law is when such a rule is infringed. Only provisions of the first category need to be clearly comprehensible to the ordinary citizen; provisions falling within the latter category may be drafted in such a way that only legally trained readers can understand them. I would rather see only provisions of the first category in a new code: in the event of a conflict not everyone is able to have access to a lawyer.

It has been argued recently that clarity and simplicity are not necessarily advantages in a civil code: either they are unattainable or the price of attaining them is too high $^{45}$. I cannot agree with this contention. Simplicity may be attained by adding examples to rules which are formulated in an abstract way. (Obviously it should be made clear that these examples do not limit the scope of the rules concerned). Clarity may be gained by providing an explanatory memorandum.

Drafting explanatory memoranda has been a major concern of the legislators working on the new code. In order to keep the actual provisions as short as possible, the examples, and even the important clarifications, are often not given in the main body of the text. This technique, which is unknown in legal systems where the courts may not examine the parliamentary proceedings when interpreting a legislative provision ${ }^{46}$, also has its drawbacks. When the parliamen-

44. Another, less idealistic reason for the simplicity of the Swiss code's language was that not only should it be applied by the sophisticated lawyers of cities such as Zürich, but also by the lay judges of the old Forest Cantons, for the most part peasants, see F.H. Lawson, A common law lawyer looks at codification, Inter-American Law Review 1960, 1 at 2.

45. Gordley, o.c. (footnote 30 supra), on p. 140.

46. The judiciary's competence or discretion to use the parliamentary record is apparently a major element for the success or failure of a codification effort. Michael Kerr, Chairman of 
tary history is as protracted as in the case of the New Civil Code, it is often difficult to find one's way through the proceedings. This raises the question whether it would not be possible to have one authoritative explanatory memorandum to replace the lengthy parliamentary proceedings. A well-known example of such a memorandum is the Tunc commentary on the uniform sales laws of 1964 . Although the idea may be challenging, it seems incompatible with Dutch tradition.

\subsection{National Unity Versus International Unity}

The codification movement of the early nineteenth century had one serious drawback. While the newly drafted codes certainly promoted legal unification within the boundaries of national states, at the same time they endangered the international character of legal science. Legal studies no longer concentrated on the common basis of all legal systems, but rather on each particular country's own positive law. Comparative law safeguarded against the danger of provincialism, but because of its somewhat esoteric nature the influence of comparative law has never been profound.

A more important threat, especially to national codes, came from the international unification and harmonisation of private law. In the area of commercial law, many international conventions have found their way - often adapted to the Dutch legal system - into the Commercial Code. Nevertheless, a number of conventions have remained outside the main codes. I have already mentioned the probable fate of the originally proposed Book 9 on intellectual and industrial property: because of the Benelux unification in this area, it no longer seems feasible to include this part of the law in the New Civil Code. Another important piece of legislation which has remained outside the present Civil Code, and which will remain outside the New Civil Code, is the uniform legislation on international sales of movable goods (i.e., the present Hague Conventions and, in the near future, the 1980 Vienna Convention). The legislature has adapted the regulation of domestic sales in the New Civil Code to international uniform law, but it would still be inappropriate to incorporate this corpus alienum - with its proper rules of interpretation, its internationally known classification into articles and its partly foreign concepts - into the new code.

Since more international uniform legislation is envisaged, it is likely that in future more law will be outside the New Civil Code.

Where no uniform laws exist, as is the case in most areas of civil law in the narrow sense (excluding commercial law), the new code is often based on extensive comparative studies. This is clear from the explanatory memorandum, which - especially in the case of Book 6 - resembles a treatise on comparative law. If the

the (English) Law Commission, in his essay on 'Law reform in changing times', 96 Iaw Quarterly Review 515, 527-528 (1980), argues that the failure of the English codification effort 'stems from a basic and apparently ineradicable feature of our constitutional philosophy: all our legislation is based on the premise that Parliament is not merely concerned with the formulation of general principles to be applied by the courts, but that every statute must, as far as possible, seek to cover every foreseceable situation'. 
legislature has in some instances followed a direction which is out of line with other European codes, it has at least done so with open eyes.

\subsection{A New Code Enters into Force: Evolution or Revolution?}

It has often been observed that a revolutionary era is favourable for the development of new civil codes. Even the French Civil Code, which is usually thought of as a compromise between revolution and tradition ${ }^{47}$, brought about important changes $^{48}$. As will be apparent from the previous paragraphs, the entry into force of Books 3-7 of the New Civil Code will also mark a turning point in the history of Dutch private law. Nevertheless, the emphasis will be more on the changes in structure and terminology than on changes in substantive law.

As far as substantive law is concerned, the differences between the old and the new code have watered down in two ways. First, the new code was originally devised to be no more than a revision of the law and it is therefore natural that many provisions are in accordance with present law. Secondly, the New Civil Code itself has already exercised considerable influence on the interpretation of the present Civil Code. This development will be explored in greater detail below.

The application by the courts of laws which have not (yet) entered into force is not a new phenomenon. In the most important case ever decided upon by the Hoge Raad, the historic decision in Lindenbaum v. Cohen ${ }^{49}$, the basis for the court's ratio decidendi was supplied by a bill which was lodged with parliament. Similarly, bills on labour conflicts and on conflict of laws, and even draft bills, have been applied without ever having entered into force. However, the New Civil Code has given rise to an extremely large number of cases in which the new law was applied before it had entered into force. This has no doubt been enhanced by the fact that the new code has remained a subject for discussion for so long.

Interpretation in an anticipatory sense ${ }^{50}$ is found in two separate forms. First, in a number of cases the courts have merely adopted the terminology of the new code. Thus, the term "good faith" in the law of obligation has been renamed "reasonableness and equity", following the New Civil Code ${ }^{51}$. Another example is the case law on causation; its terminology has been influenced by the new code, although the code in its turn has mainly been a codification of the new causation theory adopted by the Hoge Raad in the 1970's. ${ }^{52}$

47. Cf. C.J. Friedrich, The ideological and philosophical background, in: Bernard Schwartz (ed.), The Code Napoléon and the common-law world, New York 1956, p. 1, at p. 4.

48. Such as civil marriage, divorce, limitation of the inheritance of the first-born son, limitation of the fideicommissum, mortgage, abrogation of feudalism, etc.

49. Hoge Raad 31 January 1919 W 10365 (Mff).

50. The term was coined by G.J. Scholten, Anticiperende interpretatie, een nieuwe interpretatie-methode, WPNR 1969 nrs. 5031/5032.

51. Regarding this terminology, see the contribution by J.L.M. Elders to the forthcoming volume E radice arbor (essays in honour of Judge L. Erades).

52. See Keith Dill Nunes, Toward meaningful Criteria of Actionability in the Law of Delict, in: Comparative Law Yearbook vol. 3, 1979, p. 173-213. 
Secondly, and more importantly, the courts have brought about a number of substantive changes in Dutch law ${ }^{53}$. Dutch lawyers have sometimes been baffled by the question of why the Hoge Raad did apply the new code in some cases and did not in other cases. In Van de Witte v. Bosch ${ }^{54}$, the court gave some clues regarding this question. Art. 1404 Civil Code, which until then had been interpreted as implying a fault liability for the owners of animals, with only a reversal of the burden of proof, was suddenly considered to imply a strict liability. The court's reasoning clearly shows that the decisive arguments include: the fact that the previous jurisprudence of the court met with almost universal criticism, and has not been followed in a number of cases decided upon only in the first instance; parliamentary proceedings of the bill (as it then was) are in an advanced phase; the text of the provision of the present code does not necessarily support the former view; and finally the opinions on the question involved have developed in a certain direction which has led to the new text. Apart from these arguments, it seems probable that the following considerations are also important: the desirability of a flexible and easy transition from the old to the new code, both with regard to terminology and substance; the urgency of the reform; the probability of the draft provision entering into force; in the case of a draft bill, the authority of the author of the draft; the economic and legal implications of a change in the law ${ }^{55}$.

Finally, it should be noted that the entry into force of Books 3-6 of the New Civil Code quite probably will not mean that civil law will once again be a "quiet possession", without any major changes. The development of family law after Book 1 of the new code entered into force in 1970, is proof to the contrary, as is the development of the law of juristic persons since Book 2 entered into force in 1976.

As far as family law is concerned, divorce by common consent was introduced only a year after Book 1 had entered into force. The legal position of children born out of wellock is only now being brought in line with that of children from married parents. The age of majority is in the course of being reduced to eighteen. The primacy of the husband is also only now being significantly reduce ${ }^{56}$.

There is more to come, for much remains to be done: the principle of guilt should be removed from divorce law altogether; unmarried partners should be pro-

53. See C.J. van Zeben, Een koperen feest, inaugural lecture Rotterdam, Deventer 1966 and for a more up to date survey of decisions applying the New Civil Code C.J. van Zeben and G.J.L. Seesink (eds.), Nieuw Burgerlijk Wetboek, Deventer 1959 - (looseleaf), Rechtspraakoverzicht, which lists more than eighty decisions.

54. Hoge Raad 7 March 1980 NJ 1980, 353 (note G.J. Scholten). See also J. Rombach, WPNR 1980 nrs. 5541/5542.

55. One year before Van de Witte v. Bosch, the Hoge Raad had refused to apply the New Civil Code provision on strict liability for dangerous substances by way of anticipation. Hoge Raad 22 June 1979 NJ 1979, 535. This refusal was attributed to the possible economic and legal consequences of a major change in this area. Another argument against the application of the new law may have been that the provision establishing liability may be supplemented, by virtue of another provision, by a decree limiting the maximum amount to be recovered. This decree has of course not yet been issued.

56. Regarding the changes in Dutch family law see W.L. Haardt, Familierecht op drift, Tijdschrift voor privaatrecht 1979, 159-171. 
vided with a firm legal basis for their financial relation; children should be given the right to choose the name of their mother, etc. At the moment it seems unlikely that family law will remain unchanged in the near future.

Similarly, the law of juristic persons has continued to change, particularly because of the impact of EC directives in the area of corporation law.

\subsection{Re-educating the Legal Profession}

A Civil Code is a cornerstone of legal practice and it is therefore understandable that the legal profession has viewed the enactment of a New Civil Code with considerable distrust. Familiar concepts, such as fiducia cum creditore and force majeure will simply vanish, or rather their function will be taken over by new legal institutions. The content of many provisions in the code, which are familiar to all practicising attorneys, will be changed and all provisions will be renumbered. The whole structure of the code is new, especially its new General Part (Book 3). How is the legal profession to be re-educated (i.e., nearly 4,000 practising attorneys, 650 judges, nearly 2,000 notarissen and kandidaat-notarissen, and all the others engaged in legal work, numbering at least 18,000 in total, although of course not all of these are engaged in civil law ${ }^{57}$ )?

First of all, it should be pointed out that the introduction of the new code will not come about suddenly. The most important commentaries already devote considerable attention to the New Civil Code. At the annual meetings of the Nederlandse Juristen-Vereniging, an association modelled on the Deutscher Juristentag, the themes for discussion are often chosen from the new code, as are the subjects of many other law associations' meetings. The reasons for this interest have already been given above in sect. 3.6; not only is there a natural concern about ius constituendum, it is also widely known that when in doubt a court will often turn to the New Civil Code to find a solution or arguments for a solution even though the code may not yet be in force. (This is obviously a self-enforcing development, as the court's search for newly codified principles is promoted by attorneys who themselves use the commentaries mentioned above). In this way, many Dutch lawyers have become familiar with at least parts of the new code.

Secondly, as early as 1979 a number of post-graduate courses were offered to lawyers who were interested in becoming familiar with the code's system. The most important of these programmes consists of a twenty hour course, spread over ten weeks, which is now scheduled to atract some 4,500 lawyers, who will be divided into 132 groups meeting in all the major Dutch cities Juring 1982-1985. A little more than $70 \%$ of these classes will be taught by university teachers, the remaining $30 \%$ by practising attorneys. In the first half of 1982 , the first group of some eighty teachers was instructed by top civil servants from the Ministry of Justice. ${ }^{58}$

57. Numbers taken from N.H.M. Roos, Juristerij in Nederland/Sociale ontwikkelingen in de opleiding en de beroepen van juristen, Deventer 1981, pp. 97-148.

58. This is nothing new of course: in the sixth century Emperor Justinian had made provisions for education with his new codification. 
This programme is not the only major course being offered to the legal profession. The judges and the notarissen and kandidaat-notarissen have developed their own courses. Some commercial companies are also offering courses on the New Civil Code. Moreover, it is expected that some of these courses will encourage major law offices to begin their own intra-mural training.

"Après nous le déluge" may sum up the attitude prevalent among a small number of old and nearly-retired members of the bench and the bar. On the whole, however, the profession is working hard to ensure that it is not overwhelmed by the entry into force of the New Civil Code by 1985.

Are Dutch law students instructed in the new code? Surprisingly, this still does not seem to be the case. Some law faculties now offer optional courses on the New Civil Code and many of the solutions offered by the new code are dealt with in ordinary civil law courses. However, the structure of the courses still reflects the old Burgerlijk Wetboek. Why are the faculties so slow in adapting their curricula to the new code? One major obstacle is the absence of textbooks. Naturally, it should be borne in mind that it is not a very rewarding job to write a textbook about a code which has not yet entered into force ${ }^{59}$. The provisions of the code still have to be definitively numbered, the bills for introduction may amend the code's provisions to some extent, and finally, until the code has entered into force one cannot be $100 \%$ certain that it actually will. Even so, some textbooks have already been published: Hartkamp's Compendium ${ }^{60}$ and Schoordijk's commentary on Book $6^{61}$. However, these books are not sufficient for use in a basic course: the Hartkamp book is an excellent companion to the study of the New Civil Code, but it cannot replace (and is not intended to replace) a textbook; the Schoordijk volume is very erudite and probably too scholarly for use by second year law students.

Fortunately, some other study aids are now available. First, the Parliamentary proceedings of the enactment of Books 3,5 and 6 - and at an earlier date, of Books 1 and 2 - have been published ${ }^{62}$ and an inexpensive student edition ${ }^{63}$ has been prepared for publication. Secondly, a plethora of law review articles on the New Civil Code ${ }^{64}$ makes it possible to compile Readers, which may diminish the problems resulting from a lack of detailed textbooks. Thirdly, it should be remembered that the existing textbooks, even though they are not yet up to date

59. Similarly, it is unrewarding to write a textbook on a law which will soon cease to be applied. This may be the reason why in some areas of Dutch law - most notably the law of succession and sales law - hardly any textbooks have been published during the iast twenty years.

60. A.S. Hartkamp, Compendium van het vermogensrecht volgens het Nieuwe Burgerlijk Wetboek, Deventer 1977.

61. H.C.F. Schoordijk, Het algemeen gedeelte van het verbintenissenrecht naar het Nieuw Burgerlijk Wetboek, Deventer 1979.

62. C.J. van Zeben and J.W. du Pon, in co-operation with M.M. Olthof, Parlementaire geschiedenis van het Nieuwe Burgerlijk Wetboek, boeken 3, 5 en 6, Deventer 1981 (Three volumes).

63. M.M. Olthof en J.W. du Pon, Studenteneditie parlementaire geschiedenis NBW boeken 3, 5 en 6, Deventer 1982 .

64. See Van Zeben-Seesink, o.c. (footnote 4 supra). 
with the New Civil Code's system, often devote considerable attention to the new code.

Finally, I would like to draw attention to the question of how foreign lawyers and legal scholars can be informed about the new code. The language barrier will prevent most foreigners from taking a closer look at the code. A major problem is that a translation of the text alone is not enough. As so many details are not settled by the text but by the explanatory memorandum, the latter should also be consulted, and therefore translated. Fortunately, Book 1 is available in a French translation and Book 2 in an English translation. An earlier draft of Book 6 has been published in English and the present text of Books 3, 5 and 6 is being translated by two Dutchmen living in Canada, where the Province of Quebec has taken an interest in the new Dutch code in connection with its own recodification project. 